UNNES Journal of Biology Education

\title{
The Effectiveness of Team Games Tournament with Edmodo on Students' Learning Outcome and as an Attempt to Support the Pillar of Paperless Conservation
}

\author{
Ibnu Rizaki ${ }^{1 凶}$, Endah Peniati $^{1}$, Eling Purwantoyo ${ }^{2}$
}

Department of Biology, FMIPA, Universitas Negeri Semarang, Indonesia

\begin{tabular}{ll}
\hline Info Articles & Abstract \\
\hline History Articles: & Model and learning media is the important component that can affect the result of learning \\
Received : January 2019 & outcomes. The appropriate model of learning can improve students learning activity. The result \\
Accepted : March 2019 & of interest questionnaire and interview with biology teachers in SMA N 1 Jatibarang showed \\
Published : April 2019 & that student activity interest at medium category and paper became the main option for all \\
\hline Keyword: & administration and documentation needs. Team Games Tournament with Edmodo was rated as \\
team games tournament & the most appropriate model that match the situations and conditions in SMA N 1 Jatibarang \\
edmodo & nowadays. This model has high efficacy level to solve the activity and learning outcome \\
paperless conservation & problem, meanwhile, Edmodo is the proper rated class-based website as the solution for paperless \\
& attempt. This study aim is to evaluate the effectiveness of Team Games Tournament with \\
& Edmodo toward student learning outcome and as an attempt to support the pillar of paperless \\
& conservation in SMA N 1 Jatibarang. A pre-experimental, One Group Pretest-Posttest Design was \\
& used. Samples was collected by purposive sampling methods. All XI MIPA students used as \\
& experiment class. Data collection method in this study is a test and questionnaire-based \\
& methods. Data analysis result showed that classical mastery at 93.26\% and N-gain score at 0.70 \\
with high category. The student opinion towards TGT method with Edmodo has a very good & category. The conclusion is Team Games Tournament model with Edmodo effective towards \\
student learning outcome and as an attempt to support the pillar of paperless conservation.
\end{tabular}

(C) 2019 Universitas Negeri Semarang

\footnotetext{
$\square$ Correspondence:

Building D6 Lt.1 J1 Raya Sekaran Gunungpati Semarang

E-mail: anarizaki@yahoo.com
} 


\section{INTRODUCTION}

Study is defined as a change in behavior in a person who is relatively settled as a result of an experience (Slameto 2010). Learning outcomes can be in the form of behavioral changes and are usually written in the form of score or numbers through an evaluation process that has been given by the teacher. Study requires two-way interaction between teachers and students. Septiyaningsih (2017) said that there is a positive and significant influence on learning activities toward learning achievement. If learning activities increase, learning achievement also increases. Teachers need to design models, methods and determine the appropriate media for each material presented. The learning model designed by the teacher must adjust the students character and the character of the material presented. The development of information technology and the widespread of internet networks to remote areas have created new concepts in IT-based learning or known as e-learning. E-Learning or Online Learning is a system and learning process that is implemented online by utilizing internet technology (Dharmawati 2017).

The results of the interest questionnaire and the interview with the biology teacher at SMA N 1 Jatibarang obtained data that the interest in student activities was in the medium category and paper became the main choice for all administration and documentation needs such as Student Worksheets, giving structured assignments, and daily test questions and answers. The innovation of converting data from paper text to digital has not been done.

Semarang State University is expected to be able to create graduates who organize and develop superior education and international insight. In accordance with the vision of becoming as an university of conservation with international reputation. Science develops very quickly demanding students to self-internationalize the technological development of education. In addition, the use of e-learning is also an attempt in conservation in the field of paperless education.

Team Games Tournament is precisely used to overcome the problem of student activity and learning outcomes. Based on research by Surya \& Sitorus (2017), the Team Games Tournament model is one type or model of cooperative learning that is easy to implement, involves the activities of all students, increase creativity and contains elements of competition. Learning is more perfect if the model is combined with e-learning. E-learning use a class-based website i.e. Edmodo. The application of the Team Games Tournament learning model with Edmodo media is expected to provide opportunities for students to learn in an atmosphere that is active, easy and capable of conservation behavior. Of course, this can affects the level of concentration, the speed of absorbing the subject matter so that it results in maximum learning outcomes.

\section{RESEARCH METHOD}

This study used pre-experimental design. The study was conducted since April until May 2018 at SMA N 1 Jatibarang, Brebes Regency using One-Group Pretest-Posttest Design that is there are groups that are defined as experimental groups. The research group consisted of students of class XI MIPA 1, MIPA 2, MIPA 3, MIPA 4. The data of this study were posttest scores as learning outcomes as well as student and teacher responses to learning with Edmodo media. The effectiveness referred to in this study is the success rate of the application of Team Games 
Tournament with Edmodo media towards student learning outcomes in class XI MIPA SMA $\mathrm{N} 1$ Jatibarang. Learning is effective when classical mastery is achieved at least $80 \%$ of the experimental class students obtain posttest score $\geq 65$ (KKM) according to the completeness of learning biology at SMA N 1 Jatibarang, $N$-gain score category of experimental class is high.

\section{RESULT AND DISCUSSION}

This study aim is to evaluate the effectiveness of Team Games Tournament with Edmodo toward student learning outcome and as an attempt to support the pillar of paperless conservation. Data analysis used to determine learning outcomes is classical mastery and $\mathrm{N}$-gain score. Whereas student opinion questionnaires and teacher responses were used as supporting data.

\section{Posttest Score}

Table 1 Posttest score of experimental class with TGT model on Immune System subject

\begin{tabular}{lccccc}
\hline \multirow{2}{*}{ Class } & $\begin{array}{c}\text { Student } \\
\text { number }\end{array}$ & \multicolumn{2}{c}{ Score } & Average & $\begin{array}{c}\text { Classical mastery } \\
\text { (\%) }\end{array}$ \\
\hline XI MIPA 1 & 29 & 95 & 60 & 76.21 & 93.1 \\
XI MIPA 2 & 31 & 95 & 55 & 79.68 & 93.54 \\
XI MIPA 3 & 30 & 90 & 50 & 77.5 & 90 \\
XI MIPA 4 & 28 & 90 & 60 & 79.82 & 96.42 \\
Average & & & & & 93.26 \\
\hline
\end{tabular}

Data showed that posttest score average for each experimental class has exceeded the KKM of 65 . Students' learning result showed classical mastery reach $>80 \%$ in all classes by applying TGT method. Based on this result, can be stated that learning model by Team Games Tournament method effective towards student learning outcomes.

\section{$N$-gain Analysis}

$\mathrm{N}$-gain test is used to determine the increase of learning outcome between pretest and posttest after the grant of preferential treatment.

Table $2 \mathrm{~N}$-gain analysis result of experimental class with TGT model on Immune System subject

\begin{tabular}{|c|c|c|c|c|c|}
\hline \multirow{3}{*}{ Class } & \multicolumn{3}{|c|}{ Number of student } & \multirow{3}{*}{$\begin{array}{l}\text { Average of } \\
N \text {-gain score }\end{array}$} & \multirow{3}{*}{$\begin{array}{r}\text { Category } \\
\text { Average }\end{array}$} \\
\hline & \multicolumn{3}{|c|}{ Category } & & \\
\hline & Low & Medium & High & & \\
\hline XI MIPA 1 & - & 16 & 13 & 0.6745 & Medium \\
\hline XI MIPA 2 & - & 11 & 20 & 0.7181 & High \\
\hline XI MIPA 3 & - & 13 & 17 & 0.6925 & Medium \\
\hline XI MIPA 4 & - & 13 & 15 & 0.7139 & High \\
\hline Average & & & & 0.6998 & \\
\hline
\end{tabular}

Table showed that each class encountered an average increase in learning outcome with $\mathrm{N}$-gain score at medium and high category. There is no class with low $\mathrm{N}$-gain score. 


\section{Student's Opinion}

The data about student opinion toward Team Games Tournament model is taken in the form of questionnaire the was given to the students using Edmodo polling feature and interview against three students at the end of learning process.

Table 3 Student's Opinion Toward TGT Model Learning with Edmodo media on Immune System subject.

\begin{tabular}{|c|c|c|c|}
\hline No & Asked Aspect & Percentage & Criteria \\
\hline 1. & The learning atmosphere is interesting, fun, and challenging & $90 \%$ & Very good \\
\hline 2. & Students boldly suggested or answer & $92 \%$ & Very good \\
\hline 3. & Improve the scientific attitude & $89 \%$ & Very good \\
\hline 4. & $\begin{array}{l}\text { Strengthening relationship with classmates in learning } \\
\text { groups }\end{array}$ & $88 \%$ & Very good \\
\hline 5. & Motivation to learn more actively and be the best in class & $85 \%$ & Very good \\
\hline 6. & $\begin{array}{l}\text { Video animation can strengthen memory regarding immune } \\
\text { system subject }\end{array}$ & $89 \%$ & Very good \\
\hline 7. & $\begin{array}{l}\text { Video animation is attractive because it accompanied by } \\
\text { images and sounds. }\end{array}$ & $84 \%$ & Very good \\
\hline 8. & Video animation makes it easy to understand the subject & $84 \%$ & Very good \\
\hline 9. & $\begin{array}{l}\text { Video animation helps in learning anywhere through } \\
\text { Handphone/Smartphone }\end{array}$ & $87 \%$ & Very good \\
\hline 10. & $\begin{array}{l}\text { Video animation helps found and see microscopic objects } \\
\text { that are associated with the immune system subject }\end{array}$ & $94 \%$ & Very good \\
\hline 11. & Biology learning with Edmodo more efficient in time tasking & $84 \%$ & Very good \\
\hline 12. & $\begin{array}{l}\text { Edmodo helps me communicate with teachers and } \\
\text { classmates }\end{array}$ & $92 \%$ & Very good \\
\hline 13. & $\begin{array}{l}\text { Edmodo improve my skill using computer } \\
\text { technology/internet }\end{array}$ & $87 \%$ & Very good \\
\hline 14. & $\begin{array}{l}\text { Edmodo arouse me to more wisely use the internet as a } \\
\text { learning source }\end{array}$ & $80 \%$ & Very good \\
\hline 15. & $\begin{array}{l}\text { Edmodo train me for independent study in search of new } \\
\text { sciences }\end{array}$ & $91 \%$ & Very good \\
\hline 16. & Edmodo can reduce the paper use for learning & $93 \%$ & Very good \\
\hline 17. & $\begin{array}{l}\text { Edmodo is my attempt to support environmental } \\
\text { preservation }\end{array}$ & $90 \%$ & Very good \\
\hline 18. & $\begin{array}{l}\text { Edmodo retrain my conservation soul in the field of } \\
\text { education }\end{array}$ & $91 \%$ & Very good \\
\hline 19. & $\begin{array}{l}\text { Edmodo can save on costs incurred for the purchase of paper } \\
\text { and stationery }\end{array}$ & $94 \%$ & Very good \\
\hline 20. & $\begin{array}{l}\text { Edmodo arouse me to implement a conservation attitude in } \\
\text { daily life. }\end{array}$ & $91 \%$ & Very good \\
\hline
\end{tabular}

\section{Result of Student's Cognitive Learning}

Learning by Team Games Tournament model with Edmodo media is effective on student learning outcomes in the Immune System subject. The experimental class gets classical mastery at $93.26 \%$ or more than the indicator of effectiveness that is equal to $80 \%$. The $N$-gain score of experimental class shows an increase in learning outcomes with high category. The average $N$-gain score obtained is 0.701 . Each student experienced an increase in value between the pretest and posttest. Even so, there are 8 students getting posttest scores under the KKM. 
Learning by TGT model in this study used a variety of learning media. The media used are powerpoint slides, video animation, and Edmodo as an online class. Media is one of the factors that support the success of learning. Students have different ways of learning. The more varied the media used, the easier it is for students to understand the material (Roihana et al. 2018).

The first syntax of the Team Games Tournament model is class presentation. Class presentations are conducted by teachers using powerpoint media and video animations. Video animation presents images and sounds that can attract students' attention. The results of student opinion showed $84 \%$ agreed that video animation were interesting and could strengthen memories in learning material. The material delivered through animation provides a clearer and closer to real picture that can improve student understanding (Sukiyasa \& Sukoco 2013).

The next phase in the TGT model is learning in groups. The design of discussion and group learning aims to increase student activity. The activity in meaning is student activities that lead to the learning process such as asking questions, submitting opinions, working on assignments, presentations, and discussions with groups. Learning activities are expected to improve student learning outcomes. Based on research conducted by Kinaseh et al. (2015), it shows that there is a linear relationship between activity and learning outcomes. Students who have high activity, the learning outcomes and learning achievements are also high.

The quiz tournament is an attempt by the teacher to create a serious but relaxed atmosphere in learning. The atmosphere of the learning environment can improve students' learning achievement. Environmental conditions in which students are actively involved in the classroom, the freedom of students to express themselves and good interaction between students can improve learning achievement (Suranto 2015). Tournament activities get a positive response from the teaching teacher. According to him, tournaments make the atmosphere of learning relaxed so students do not get bored during learning.

The end of the Team Games Tournament learning model is the awareness where the score of the results of the tournament is calculated and the winner group is announced. The winning group is based on the highest total score. Natalia et al. (2014) stated that awarding by teachers can increase students' motivation to be more achievable. Awards can also teach students that studying hard can produce useful results.

\section{Learning by Edmodo Media}

Biology learning utilizing Edmodo starts with making class accounts, which consist of teachers and students, then grouped based on their respective classes. Edmodo has many features that teachers can use in online learning management. The student's Edmodo system features include alerts, notes, assignments, quizzes, and progress.

The polling and discussion forum features are used by the teacher to send the topic of discussion as a starter thread and provide opportunities for students to participate in giving responses like netizens on social media in general. Of course, the responses are in accordance with the topic. This feature has a positive impact on students. The students opinion by $92 \%$ states that learning biology utilizes Edmodo makes it easier for students to communicate with teachers and classmates. This feature indirectly provides an opportunity for shy students in the class to actively express their opinions about the material presented by the teacher.

Evaluation of learning in this study uses the quiz feature as a substitution for test paper. The items previously made by the teacher are then sent to each class. The quiz feature on 
Edmodo can be multiple choice questions or essays. The pretest and questionnaire of student opinion was done through the quiz feature. The advantages of this quiz feature are the teacher can determine the number of questions, scramble the questions, and provide a time limit for workmanship, thereby reducing the opportunity for students to cheat on the questions. The students also have benefit from time efficiency and save on the use of stationery.

Biology learning with Edmodo in this study has advantages over conventional learning. The response of students is very good (84\%) stating that biology learning uses Edmodo to be more time efficient in doing tasks and facilitate communication with teachers and classmates (92\%). Research by Kurniawati \& Djuniadi (2015) stated that Edmodo media can be used to channel messages that stimulate the mind, feelings, attention, and willingness of the learning so that it can encourage the occurrence of deliberate, purposeful, and controlled learning.

Learning using a computer gets a positive response from the teacher. Based on the results of the interview stating that learning improves students' skills in using computers and trains students to be more wise in utilizing internet access. Skills for using computers are needed by students because the national examination system is computer based. It is expected that students will not find difficulties in doing the exam later in class XII.

In general, Edmodo provides advantages and ease in the learning process, but in the implementation of this study, there were several obstacles. One of the obstacles is slow internet connection. Edmodo is an online site so internet access is a requirement that must be fulfilled before using it. Internet connection in research schools is quite slow so students need a long time just to open Edmodo. The effective time of learning is reduced so that the teacher must readjust the learning design that has been made. In addition, the number of computer units in one room is less than the number of students in one class. This causes some students to use computers alternately.

\section{Attempt to Support The Pillar of Paperless Conservation}

Paperless attempt is one of the pillars of the conservation of the Universitas Negeri Semarang. In accordance with the Rules of the Rector of the Universitas Negeri Semarang No. 27 year 2012 about the campus-based Governance of conservation in Universitas Negeri Semarang. Article 7 reads that paperless policy pillar program is applied through the optimization of information technology-based systems, efficient use of paper, the utilization of recycled paper, and the use of environmentally friendly paper.

The research is applying one of the pillars of conservation namely paperless. Study carried out utilizing electronic media and the internet as substitution to reduce the paper use. Biology learning on experimental class used Edmodo media. Learning process completely does not require paper because the administration needs such as student presence, subject matter, and the evaluation can be done through Edmodo. Such activity is supporting conservation of the paperless in education.

Learning use Edmodo received very good (93\%) by students opinion in reducing the use of paper. Paper needs replaced entirely by the computer usage and applications supporting like Edmodo and powerpoint. Edmodo have a student presence feature and recapitulation of the student value so that the daily needs of presence book and value book already replaced.

The student's knowledge about the preservation of the environment encourage students accept and support Edmodo as the paperless behavior. Using Edmodo is one of the attempt in favor the environmental preservation. As much as $90 \%$ of the students opinion agreed with the statement. In addition of knowledge, train students directly participate in the preservation of 
the environment is also important to behave. Concern for the environment is not entirely innate instinct or talent but is also the result of a process of education in the broad sense (Afiani et al. 2017).

Paperless have benefits not only for the environment but also to our own. For the environment, to maintain the sustainability of the forest, keeping the existing flora and fauna in the forest so that it does not become extinct, preventing the occurrence of forest degradation, preventing global warming, offset the amount of carbon that is in the Earth. While the benefits to humans i.e. efficiency against production costs, reduced air pollution and others. The study also received $94 \%$ of students agreed that Edmodo could save costs incurred to buy paper and stationery.

Paperless attempts in learning is not easy to do. Paperless attempt need time to be accepted by the entire school. Things that are prepared are facilities such as computers, internet connections, education-based computer applications. Human resources i.e. teachers and students also need to be prepared. Ability to use digital media become a capital important that teachers can operate and develop digital media e.g. Edmodo in accordance with the subject matter and the school environment.

\section{CONCLUSION}

Based on the results of research and discussion, it can be concluded that the model of Team Games Tournament with Edmodo media is effective against learning outcomes and as an attempt to support paperless conservation pillars. The results of the data analysis showed the classical completeness value of $93.26 \%$ and the $\mathrm{N}$-gain score of 0.70 in the high category. Student responses to the TGT model with Edmodo media are in very good category.

\section{REFERENCES}

Afiani H, SME Susilowati, N Subekti. 2017. Penerapan Model GI dan PBL dengan Limbah Batik sebagai Sumber Belajar terhadap Hasil Belajar dan sikap Peduli Lingkungan. Journal of Biology Education. 6: 80-87.

Dharmawati. 2017. Penggunaan media e-Learning berbasis Edmodo dalam pembelajaran English for Business. QUERY Jurnal Sistem Informasi 1:43-49

Kinaseh, N Subekti, TA Pribadi. 2015. Pengaruh model problem based learning dengan media animasi flash terhadap hasil belajar dan aktivitas siswa. Unnes Journal of Biology Education 4: 317-321

Kurniawati R \& Djuniadi. 2015. Pengembangan media blended learning berbasis edmodo di sekolah menengah kejuruan. Indonesian Journal of Curriculum and Educational Technology Studies 3: 16-24.

Natalia, I Salim, R Rasyid. 2014. Pengaruh pemberian penghargaan oleh guru ekonomi terhadap motivasi belajar siswa kelas X MAN 2 Pontianak. Jurnal Pendidikan dan Pembelajaran 3: 1-11.

Roihana RZ, KK Pukan, A Irsadi. 2018. Usage effectiveness of video and Mama Card in biology learning of reproductive system. Journal of Biology Education 7: 54-63.

Septiyaningsih S. 2017. Pengaruh aktivitas belajar dan kemandirian belajar terhadap prestasi belajar mahasiswa. Jurnal Pendidikan dan Ekonomi 6: 264-275.

Slameto. 2010. Belajar dan Faktor-Faktor yang Mempengaruhinya. Jakarta: Rineka Cipta.

Sukiyasa K \& Sukoco. 2013. Pengaruh media animasi terhadap hasil belajar dan motivasi belajar siswa materi sistem kelistrikan otomotif. Jurnal Pendidikan Vokasi 3: 126-137.

Suranto. 2015. Pengaruh motivasi, suasana lingkungan dan sarana prasarana belajar terhadap prestasi belajar siswa (studi kasus pada SMA khusus putri SMA Islam Diponegoro Surakarta. Jurnal Pendidikan Ilmu Sosial 25: 11-19.

Surya E \& EN Sitorus. 2017. The influence of Teams Games Tournament cooperative learning model on students' creativity learning mathematics. International Journal of Sciences Basic and Applied Research (IJSBAR) 34: 16-24. 